\title{
Quantitative Evaluation of Total Cellular Number and Cellular Density in the Thymolymphatic Organs of Young Adult Albino Rats by Means of DNA Determination*
}

\author{
By \\ Yoshitoki Monden \\ Department of Anatomy (Director: Prof. B. Osogoe) and Laboratory \\ of Cýtochemistry (Director: Prof. A. S i b a t a $n \mathrm{i}$ ), \\ Yamaguchi Medical School, Ube
}

Attempts to estimate the total cellular number and the rate of cell production in the hemopoietic organs have been made in a series of studies on the rat by $\mathrm{K} \mathrm{ind} \mathrm{red}(1938,1940,1942$ and 1955). The methods employed in these studies are based on cell counts and mitotic counts of given areas in sections of the hemopoietic organs of the rat. Such procedures, however, meet with difficulties particularly in sections of lymph node, because variations in cellular density and irregular distribution of mitotic figures in different regions of lymphatic organs complicate the quantitative approach in sections and may, for this reason, cause uncertainty in the results.

In the earlier communications from this laboratory, a simple method for estimating total cellular number in lymphoid organs by means of DNA determination of whole tissue and of each nucleus has been reported, together with some preliminary results (Monden, 1955 ; O sogoe et al., 1957; O sogoe, 1958; and Osogoe and A wa y a, 1958). The present paper makes a more detailed description of the results of measurements on normal adult rats that have been carried out thus far by this method.

\section{Material and Methods}

Male albino rats of a subline of the $\mathrm{W}$ is t a $\mathrm{r}$ strain, weighing $200 \mathrm{~g}( \pm 2 \%)$, served as the material. They were maintained on a stand-

* Supported in part by a grant to Professor Bunsuke O sogo e from the Ministry of Education (Grant-in-Aid for Fundamental Scientific Research; Cooperative). 


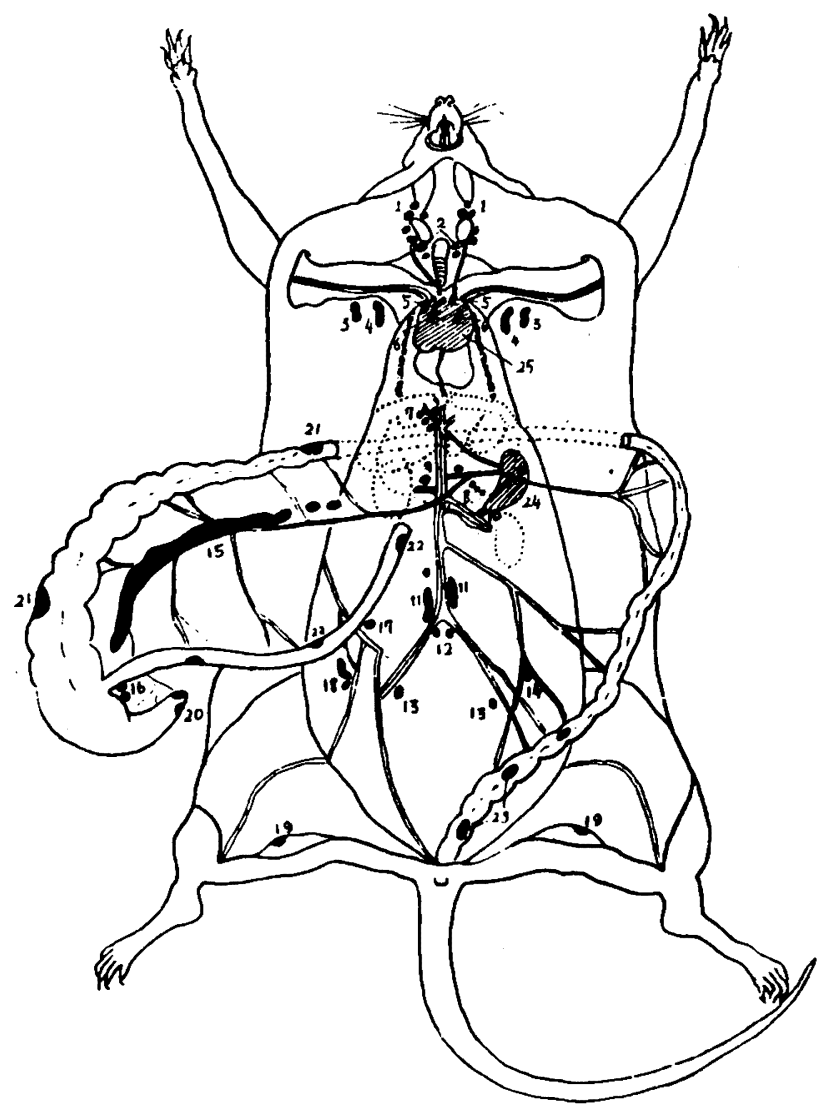

Fig. 1. Thymolymphatic organs of the rat.

1. Superficial cervical.

2. Deep cervical.

3. Superficial axillary.

4. Deep axillary.

5. Superficial mediastinal.

6. Deep mediastinal.

7. Portal.

8. Postgastric.

9. Right renal.

10. Left renal.

11. Para-aortic.

12. Sacral.

13. Iliac.
14. Mesocolic.

15. Mesenteric.

16. Cecal.

17. Posterior abdominal wall.

18. Inguinal.

19. Popliteal.

20. P e y e r's patch in the cecum.

21. Ditto in large intestine.

22. Ditto in small intestine.

23. Ditto in rectum.

24. Spleen.

25. Thymus.

The terminology is the same as used in the paper of Sanders and Flore y (1940). 
ard laboratory diet ${ }^{1}$ and water ad libitum supplemented once a week with cabbage or other vegetables. The chief reason why the albino rat was chosen for this work is that its diet and environment can readily be standardized.

For the present type of measurement, it is essential to use animals of constant weight, for with advancing age the lymphoid organs, the thymus in particular, gradually undergo involution. In addition, sex differencies in growth rate also must be considered. Taking these into account, young adult male rats weighing around $200 \mathrm{~g}$ were employed as the standard animals to be examined in the present study.

\section{(1) Determination of the total DNA content in lymphoid organs}

All lymph nodes, thymus, spleen and Peyer's patches (Fig. 1) were rapidly taken out from a sacrificed animal and chilled with ice. After weighing the tissues, they were finely minced with a pair of scissors, and homogenized with 9 volume of ice-cold $2 \%$ citric acid in a Potter Elveh je m-type glass homogenizer and made up to a volume. An appropriate volumes of this homogenate was dispensed for the $\mathrm{Schneider}$ method to determine, in duplicate, the total DNA content of the homogenate using diphenylamine reaction for the test of DNA. "A sample of calf thymus DNA (sodium salt; $\mathrm{N}: \mathrm{P}=$ 1.6; P content: $9.1 \%$ ) served as the standard.

\section{(2) Determination of the average DNA content per nucleus in lymphoid organs}

This was made by a simplified procedure of the method employed by Fuk uda and S ib at a n i (1953a) for determination of the average DNA content of rat liver nuclei. The bulk of the homogenate obtained in (1) was further diluted 5-10 fold and filtered through 8 layers of gauze to remove the fiber and clumps of unbroken cells. The dilution facilitated the sedimentation of nuclei on centrifugation. Then it was centrifuged at very low speed $(500 \mathrm{rpm})$ for $3-4$ minutes to sediment the last trace of unbroken cells along with a small amount of nuclei which formed a thin white layer on the top of the sediment. The supernatant $\left(\mathrm{S}_{0}\right)$ now contained only isolated nuclei and was quite homogeneous with respect to the distribution of nuclei.

1 The diet consisted chiefly of unpolished rice, pressed barley and dried small sardines, with a small amount of cod liver oil and minerals $\left(\mathrm{CaCO}_{3}+\mathrm{NaCl}\right)$. 
Counting of nuclei was made with $\mathrm{S}_{3}$. For this purpose duplicate 0.5$1.0 \mathrm{ml}$ samples of $\mathrm{S}_{0}$ were diluted $5-10$ fold with ice-cold $2 \%$ citric acid $\left(\mathrm{S}_{1}\right)$. Nuclei were counted on $\mathrm{S}_{1}$ in $\mathrm{B} \ddot{\mathrm{u}} \mathrm{rker}$ hemocytometer. Five $0.1 \mathrm{~mm}^{3}$ sections were counted twice and averaged. The final value of the number of nuclei was the mean of the two dilutions $S_{1}$. Two $2 \mathrm{ml}$ aliquots were taken from the original $\mathrm{S}_{\mathrm{J}}$ in separate tubes and centrifuged at $3000 \mathrm{rpm}$ for 10 minutes to sediment all the nuclei. The sediment thus obtained was then analyzed for DNA as in (1). The number of nuclei in $2 \mathrm{ml}$ of $\mathrm{S}_{\mathrm{j}}$ was calculated from $\mathrm{S}_{1}$, and the average DNA-P content per nucleus was obtained by dividing the total DNA-P content of $S_{0}$ by the corresponding number of nuclei.

\section{(3) Determination of the percentages of lymphocytes in lymphoid organs}

For this purpose, imprint preparations were made from various lymphoid organs and stained with Giemsa. Because of rather irregular distribution of lymphocytes and other cellular elements in lymphoid organs, differential cell counts were made from different portions of the imprint preparations and averaged. In each slide at least 1000 nucleated cells were counted.

\section{Results and Discussion}

The results of measurements of the mesenteric and other lymph

Table 1. Total nucleated cell counts in the mesenteric lymph nodes.

\begin{tabular}{|c|c|c|c|c|c|}
\hline Rat No. & $\begin{array}{l}\text { Weight of } \\
\text { Organ (mg) }\end{array}$ & $\begin{array}{c}\text { DNA-P } \\
\text { Content per } \\
\text { Organ (mg) }\end{array}$ & $\begin{array}{c}\text { DNA-P } \\
\text { Content per } \\
\text { Nucleus } \\
\left(\times 10^{-9} \mathrm{mg}\right)\end{array}$ & $\begin{array}{l}\text { Total Nucle- } \\
\text { ated Cells } \\
\text { per Organ } \\
\left(\times 10^{\circ}\right)\end{array}$ & $\begin{array}{l}\text { Total Nucle- } \\
\text { ated Cells } \\
\text { per } \mathrm{mm}^{3} \text { of } \\
\text { Tissue }\left(\times 10^{\prime}\right)\end{array}$ \\
\hline 1 & 380 & 0.37 & 0.70 & 528 & 1.39 \\
\hline 2 & 280 & 0.34 & 0.62 & 548 & 1.96 \\
\hline 3 & 630 & 0.80 & 0.58 & 1,383 & 2.20 \\
\hline 4 & 490 & 0.54 & 0.59 & 915 & 1.87 \\
\hline 5 & 290 & 0.30 & 0.92 & 326 & 1.12 \\
\hline 6 & 380 & 0.65 & 0.72 & 902 & 2.37 \\
\hline 7 & 400 & 0.55 & 0.52 & 1,057 & 2.64 \\
\hline 8 & 400 & 0.54 & 0.83 & 650 & 1.63 \\
\hline 9 & 350 & 0.58 & 0.79 & 734 & 2.10 \\
\hline 10 & 300 & 0.47 & 0.80 & 587 & 1.96 \\
\hline Mean \pm S.E.* & $390 \pm 33$ & $0.51 \pm 0.05$ & $0.71 \pm 0.04$ & $763 \pm 121$ & $1.92 \pm 0.15$ \\
\hline$\sigma$ & 103 & 0.16 & 0.13 & 382 & 0.47 \\
\hline$v$ & 26.4 & 31.4 & 18.3 & 50.1 & 24.2 \\
\hline
\end{tabular}

*S.E. $=$ Standard error. 
nodes, thymus, spleen and $\mathrm{P}$ e y e r's patches on 10 animals each are listed in Tables 1-5. From these data, the number of total nucleated cells in the indiviudal and whole lymphoid organs can readily be

Table 2. Total nucleated cell counts in the lymph nodes other than mesenteric lymph nodes.

\begin{tabular}{c|c|c|c|c|c}
\hline Rat No. & $\begin{array}{c}\text { Weight of } \\
\text { Organ (mg) }\end{array}$ & $\begin{array}{c}\text { DNA-P } \\
\text { Content per } \\
\text { Organ (mg) }\end{array}$ & $\begin{array}{c}\text { DNA-P } \\
\text { Content per } \\
\text { Nucleus } \\
\left(\times 10^{-9} \mathrm{mg}\right)\end{array}$ & $\begin{array}{c}\text { Total Nucle- } \\
\text { ated Cells } \\
\text { per Organ } \\
\left(\times 10^{6}\right)\end{array}$ & $\begin{array}{c}\text { Total Nucle- } \\
\text { ated Cells } \\
\text { per mm of } \\
\text { Tissue }\left(\times 10^{\circ}\right)\end{array}$ \\
\hline 1 & 870 & 0.75 & 0.70 & 1,071 & 1.23 \\
2 & 1,210 & 0.94 & 0.62 & 1,516 & 1.25 \\
3 & 1,140 & 0.64 & 0.58 & 1,103 & 0.97 \\
4 & 1,030 & 0.83 & 0.59 & 1,406 & 1.36 \\
5 & 1,040 & 0.94 & 0.92 & 1,021 & 0.98 \\
6 & 860 & 0.80 & 0.72 & 1,111 & 1.29 \\
7 & 1,180 & 0.65 & 0.52 & 1,250 & 1.05 \\
8 & 1,010 & 0.67 & 0.83 & 807 & 0.80 \\
9 & 870 & 0.87 & 0.79 & 1,101 & 1.27 \\
10 & 1,010 & 1.01 & 0.80 & 1,262 & 1.25 \\
\hline Mean \pm S.E. & $1,020 \pm 45$ & $0.81 \pm 0.04$ & $0.71 \pm 0.04$ & $1,165 \pm 79$ & $1.15 \pm 0.06$ \\
$\sigma$ & 142 & 0.13 & 0.13 & 250 & 0.48 \\
$v$ & 13.9 & 16.0 & 13.8 & 12.4 & 41.6 \\
\hline$\ldots$
\end{tabular}

Table 3. Total nucleated cell counts in the thymus.

\begin{tabular}{c|c|c|c|c|c} 
Rat No. & $\begin{array}{c}\text { Weight of } \\
\text { Organ } \\
(\mathrm{mg})\end{array}$ & $\begin{array}{c}\text { DNA.-P } \\
\text { Content per } \\
\text { Organ }(\mathrm{mg})\end{array}$ & $\begin{array}{c}\text { DNA-P } \\
\text { Content per } \\
\text { Nucleus } \\
\left(\times 10^{-9} \mathrm{mg}\right)\end{array}$ & $\begin{array}{c}\text { Total Nucle- } \\
\text { ated Cells } \\
\text { per Organ } \\
\left(\times 10^{6}\right)\end{array}$ & $\begin{array}{c}\text { Total Nucle- } \\
\text { ated Cells } \\
\text { per mm of } \\
\text { Tissue }\left(\times 10^{5}\right)\end{array}$ \\
\hline 1 & 410 & 0.63 & 0.83 & 760 & 1.84 \\
2 & 380 & 0.51 & 0.89 & 571 & 1.50 \\
3 & 360 & 0.75 & 0.54 & 1,390 & 3.85 \\
4 & 300 & 0.91 & 0.85 & 1,070 & 3.57 \\
5 & 370 & 0.82 & 0.75 & 1,093 & 2.95 \\
6 & 470 & 0.55 & 0.62 & 887 & 1.89 \\
7 & 430 & 1.08 & 0.88 & 1,227 & 2.85 \\
8 & 450 & 1.17 & 0.72 & 1,625 & 3.61 \\
9 & 450 & 0.87 & 0.68 & 1,280 & 2.85 \\
10 & 550 & 0.69 & 0.66 & 1,045 & 1.90 \\
\hline Mean \pm S.E. & $417 \pm 18$ & $0.80 \pm 0.04$ & $0.74 \pm 0.04$ & $1,094 \pm 144$ & $2.68 \pm 0.27$ \\
$\sigma$ & 57 & 0.13 & 0.13 & 455 & 0.85 \\
$v$ & 13.8 & 16.2 & 17.6 & 41.6 & 31.2 \\
\hline
\end{tabular}


calculated. The figures obtained were as follows: $(763 \pm 121) \times 10^{6}$ in the mesenteric lymph nodes ; $(1,165 \pm 79) \times 10^{6}$ in the other lymph nodes ; $(1,094 \pm 144) \times 10^{6}$ in the thymus; $(1,375 \pm 189) \times 10^{6}$ in the spleen ; $(420 \pm 33) \times 10^{6}$ in the $\mathrm{P}$ e y e r's patches; totaling $(4,823 \pm 234) \times 10^{6}$ in

Table 4. Total nucleated cell counts in the spleen.

\begin{tabular}{c|c|c|c|c|c}
\hline Rat No. & $\begin{array}{c}\text { Weight of } \\
\text { Organ } \\
(\mathrm{mg})\end{array}$ & $\begin{array}{c}\text { DNA-P } \\
\text { Content per } \\
\text { Organ }(\mathrm{mg})\end{array}$ & $\begin{array}{c}\text { DNA-P } \\
\text { Content per } \\
\text { Nucleus } \\
\left(\times 10^{-9} \mathrm{mg}\right)\end{array}$ & $\begin{array}{c}\text { Total Nucle- } \\
\text { ated Cells } \\
\text { per Organ } \\
\left(\times 10^{6}\right)\end{array}$ & $\begin{array}{c}\text { Total Nucle- } \\
\text { ated Cells } \\
\text { per mm of } \\
\text { Tissue }\left(\times 10^{5}\right)\end{array}$ \\
\cline { 2 - 5 } 1 & 1,050 & 0.93 & 0.83 & 1,120 & 1.07 \\
2 & 1,580 & 1.58 & 0.53 & 2,981 & 1.89 \\
3 & 750 & 0.84 & 0.80 & 1,050 & 1.40 \\
4 & 850 & 0.90 & 0.84 & 1,072 & 1.26 \\
5 & 600 & 0.92 & 0.82 & 1,121 & 1.86 \\
6 & 890 & 1.41 & 0.85 & 1,658 & 1.86 \\
7 & 1,200 & 0.94 & 0.80 & 1,175 & 0.98 \\
8 & 600 & 0.92 & 0.76 & 1,210 & 2.02 \\
9 & 1,030 & 0.80 & 0.79 & 1,012 & 0.97 \\
10 & 850 & 0.91 & 0.67 & 1,350 & 1.60 \\
\hline Mean \pm S. E. & $940 \pm 93$ & $1.02 \pm 0.08$ & $0.77 \pm 0.04$ & $1,375 \pm 189$ & $1.49 \pm 0.13$ \\
$\sigma$ & 294 & 0.25 & 0.13 & 597 & 0.41 \\
$v$ & 31.2 & 24.5 & 16.8 & 43.4 & 27.5 \\
\hline
\end{tabular}

Table 5. Total nucleated cell counts in the P e y e r's patches.

\begin{tabular}{c|c|c|c|c|c}
\hline Rat No. & $\begin{array}{c}\text { Weight of } \\
\text { Organ } \\
(\mathrm{mg})\end{array}$ & $\begin{array}{c}\text { DNA-P } \\
\text { Content per } \\
\text { Organ } \\
(\mathrm{mg})\end{array}$ & $\begin{array}{c}\text { DNA-P } \\
\text { Content per } \\
\text { Nucleus } \\
\left(\times 10^{-9} \mathrm{mg}\right)\end{array}$ & $\begin{array}{c}\text { Total Nucle- } \\
\text { ated Cells } \\
\text { per Organ } \\
\left(\times 10^{\prime}\right)\end{array}$ & $\begin{array}{c}\text { Total Nucle- } \\
\text { ated Cells } \\
\text { per mm } \text { of }^{3} \\
\text { Tissue }\left(\times 10^{3}\right)\end{array}$ \\
\hline 1 & 220 & 0.28 & 0.58 & 483 & 2.19 \\
2 & 220 & 0.28 & 0.53 & 528 & 2.40 \\
3 & 200 & 0.19 & 0.75 & 253 & 1.27 \\
4 & 250 & 0.26 & 0.78 & 333 & 1.33 \\
5 & 280 & 0.31 & 0.59 & 525 & 1.88 \\
6 & 400 & 0.42 & 0.84 & 500 & 1.25 \\
7 & 340 & 0.29 & 0.59 & 492 & 1.45 \\
8 & 370 & 0.21 & 0.74 & 284 & 0.77 \\
9 & 300 & 0.28 & 0.66 & 424 & 1.41 \\
10 & 220 & 0.28 & 0.72 & 388 & 1.76 \\
\hline Mean \pm S. E. & $280 \pm 25$ & $0.28 \pm 0.02$ & $0.68 \pm 0.03$ & $420 \pm 33$ & $1.57 \pm 0.16$ \\
$\sigma$ & 73 & 0.06 & 0.10 & 104 & 0.51 \\
$v$ & 26.9 & 21.4 & 14.7 & 24.8 & 32.5 \\
\hline
\end{tabular}


the whole lymphoid organs (Tables 1-6).

The proportions of lymphocytes to total nucleated cells in imprint preparations were found to be $89.7 \pm 2.0 \%$ in the mesenteric lymph nodes, $88.5 \pm 2.3 \%$ in the other lymph nodes, $97.9 \pm 0.4 \%$ in the thymus, $80.7 \pm 1.5 \%$ in the spleen, and $91.0+1.0 \%$ in the $\mathrm{P}$ e ye r's patches (Table 7).

Table 6. Total weight and total number of nucleated cells of the whole lymphoid organs of normal male rats weighing around $200 \mathrm{~g}$.

\begin{tabular}{c|c|c|c}
\hline Rat No. & $\begin{array}{c}\text { Body Weight } \\
(\mathrm{g})\end{array}$ & $\begin{array}{c}\text { Total Weight of } \\
\text { Lymphoid Organs } \\
(\mathrm{g})\end{array}$ & $\begin{array}{c}\text { Total Nucleated } \\
\text { Cells } \\
\left(\times 10^{3}\right)\end{array}$ \\
\hline 1 & 200 & 2.93 & 3,962 \\
2 & 203 & 3.67 & 6,154 \\
3 & 202 & 3.08 & 5,187 \\
4 & 202 & 2.92 & 4,792 \\
5 & 202 & 2.58 & 4,125 \\
6 & 201 & 3.00 & 5,055 \\
7 & 205 & 3.55 & 5,201 \\
8 & 199 & 2.83 & 4,566 \\
9 & 203 & 3.00 & 4,557 \\
10 & 200 & 2.93 & 4,630 \\
\hline Mean & $201 \pm 0.6$ & $3.049 \pm 0.103$ & $4,823 \pm 234$ \\
$\sigma$ & 1.9 & 0.326 & 739 \\
$v$ & 0.9 & 10.6 & 15.3 \\
\hline
\end{tabular}

Table 7. Percentages of lymphocytes in smears from different lymphoid organs of normal male rats weighing around $200 \mathrm{~g}$. Mean of 10 animals. Mean \pm S. E.

\begin{tabular}{|c|c|c|c|c|c|}
\hline \multirow{2}{*}{ Cell Type } & \multicolumn{2}{|c|}{ Lymph Nodes } & \multirow{2}{*}{ Thymus } & \multirow{2}{*}{ Spleen } & \multirow{2}{*}{$\begin{array}{c}\text { Pe y e r's } \\
\text { patches }\end{array}$} \\
\hline & $\begin{array}{c}\text { Mesenteric } \\
\text { Nodes }\end{array}$ & $\begin{array}{c}\text { Other } \\
\text { Nodes }\end{array}$ & & & \\
\hline Lymphocytes & $89.7 \pm 2.0$ & $88.5 \pm 2.3$ & $97.9 \pm 0.4$ & $80.7 \pm 1.5$ & $91.0 \pm 1.0$ \\
\hline \multicolumn{6}{|l|}{ Non-lymphocytic Cells } \\
\hline Plasma Cells & $9.5 \pm 1.9$ & $10.7 \pm 2.0$ & - & $0.7 \pm 0.1$ & - \\
\hline Reticuloendothels & $0.6 \pm 0.2$ & $0.5 \pm 0.1$ & $1.8 \pm 0.4$ & $1.8 \pm 0.3$ & $8.0 \pm 0.5$ \\
\hline Neutrophils & $0.2 \pm 0.05$ & $0.2 \pm 0.02$ & $0.2 \pm 0.09$ & $4.6 \pm 0.8$ & $0.9 \pm 0.1$ \\
\hline Eosinophils & $0.1 \pm 0.02$ & $0.1 \pm 0.04$ & $0.1 \pm 0.05$ & $1.2 \pm 0.1$ & $0.1 \pm 0.03$ \\
\hline Monocytes & - & - & - & $0.3 \pm 0.1$ & - \\
\hline Erythroblasts & - & - & - & $10.6 \pm 2.0$ & - \\
\hline Megakaryocytes & - & - & - & $0.1 \pm 0.04$ & - \\
\hline
\end{tabular}


Using the data noted above, the number of total lymphocytes in the individual and whole lymphoid organs, was then computed. The computations showed that total lymphocytes numbered $(684 \pm 123) \times 10^{6}$ in the mesenteric lymph nodes, $(1,031 \pm 106) \times 10^{6}$ in the other lymph nodes, $(1,071 \pm 145) \times 10^{6}$ in the thymus, $(1,100 \pm 169) \times 10^{6}$ in the spleen, $(382 \pm 34) \times 10^{6}$ in the $\mathrm{P}$ e y e r's patches, amounting to $(4,268 \pm 577) \times 10^{6}$ in the whole lymphoid organs ${ }^{2}$ (Table 8).

Table 8. Total number of lymphocytes present in the chief thymolymphatic organs of normal male rats weighing around 200 g. Mean \pm S. E.

\begin{tabular}{|c|c|c|c|}
\hline Organ & $\begin{array}{c}\text { Total Number } \\
\text { of Nucleated } \\
\text { Cells } \times\left(10^{\prime}\right)\end{array}$ & $\begin{array}{l}\text { Percentage of } \\
\text { Lymphocytes }\end{array}$ & $\begin{array}{c}\text { Total Number } \\
\text { of Lymphocytes } \\
\left(\times 10^{5}\right)\end{array}$ \\
\hline Mesenteric Lymph Nodes & $763 \pm 121$ & $89.7 \pm 2.0$ & $684 \pm 123$ \\
\hline Other Lymph Nodes & $1,165 \pm 79$ & $88.5 \pm 2.3$ & $1,031 \pm 106$ \\
\hline Thymus & $1,094 \pm 114$ & $97.9 \pm 0.4$ & $1,071 \pm 145$ \\
\hline Spleen & $1,375 \pm 189$ & $80.7 \pm 1.5$ & $1,100 \pm 169$ \\
\hline Peyer's patches & $420 \pm 33$ & $91.0 \pm 1.0$ & $382 \pm 34$ \\
\hline $\begin{array}{l}\text { Total Thymolymphatic } \\
\text { Organs }\end{array}$ & $4,823 \pm 234^{*}$ & & $4,268 \pm 577$ \\
\hline
\end{tabular}

* Calculated from the figures for total nucleated cells present in the chief thymolymphatic organs of individual animals and not from the data given above in the same column (cf. Table 6).

Since the average number of total lymphocytes in the circulating blood has been found to be $(132 \pm 12.0) \times 10^{6}$ from a study of 50 normal male rats weighing around $200 \mathrm{~g}$ ( $\mathrm{M}$ o $\mathrm{nd} \mathrm{e} \mathrm{n}, 1958)$, the ratio of this value to the number of total lymphocytes in the thymolymphatic system is calculated to be about one to thirty-two ${ }^{3}$. This indicates that the lymphocete reserve in the thymolymphatic system is 32 times as great as the number of lymphocytes present in the blood.

The cellular density in lymphoid organs, that is, the number of nucleated cells per unit volume of the tissue, was then computed from the weight of the organ and the number of total nucleated cells per organ, assuming the specifig gravity of the lymphoid tissue to be

2 In the earlier communications (Monde n, 1955; Osogoe et al., 1955; and O s o g o e, 1958), the corresponding figure was computed to be $(4,120 \pm 651) \times 10^{3}$. A slight increase in the figure is due to increase in the number of observations and to more accurate calculations.

3 In the earlier communications (M o n d e n, 1955; Osogoe et al., 1957; and O sog o e, 1958), the corresponding ratio was estimated to be $1: 36$. 
approximately 1.00 . The values obtained for total nucleated cells per $1 \mathrm{~mm}^{3}$ of tissue were as follows: $(1.92 \pm 0.15) \times 10^{6}$ in the mesenteric lymph nodes; $(1.15 \pm 0.06) \times 10^{6}$ in the other lymph nodes $;(2.68 \pm 0.27)$ $\times 10^{6}$ in the thymus; $(1.49 \pm 0.13) \times 10^{6}$ in the spleen; and $(1.57 \pm 0.16)$ $\times 10^{6}$ in the $\mathrm{P}$ e ye r's patches (Table 1-5). As previously expected, the cellular density is highest in the thymus and it decreases in the following order: mesenteric nodes, P e y e r's patches, spleen, lymph nodes other than mesenteric nodes.

It should be emphasized here that all of the numerical analyses made in the present study showed relatively small variation in the values obtained. As seen in Tables 1-6, the coefficient of variation in each measurement did not exceed $50 \%$ and lies in most instances between 16 and $43 \%$. It is of interest to note that the values found for total lot of lymphoid organs showed less variations than those obtained for the individual lymphoid organs (cf. Tables 1-5 and Table 6).

It is generally believed that the amount of lymphoid tissue is subject to considerable individual variation even in the animals which are of the same weight or age class and are normal according to ordinary laboratory standards. In his extensive quantitative studies of the lymphoid organ by chemical determination of the nuclear substance (nucleic acid phosphorus), A ndreas e n (1943) demonstrated that, in adult rats, the coefficient of variation in the amount of lymphoid tissue was $44 \%$ for the total lymph nodes, whereas the corresponding values for the individual lymphoid organs greatly varied between 43 and $341 \%$. The value for the thymus was $66 \%$. (The corresponding figure is $31.2 \%$ in our material.)

That the variability of our material with regard to the amount of lymphoid tissue is generally much less than that of A $\mathrm{ndreasen}$ is of particular interest. It must be borne in mind, however, that our material is too small in number to draw definite conclusions as regards the varibility of the lymphoid organs. In order to gain further information on this point, an extenssve study is now being made by S a s k i in our laboratory. The results obtained so far seem to confirm the present observations ( $\mathrm{S}$ a s a ki, unpublished observations).

The present method of evaluating total cellular number in thetissue is based principally on the constancy of the DNA content per nucleus in the diploid nuclei. The degree of accuracy or reliability of this method, therefore, depends upon whether the estimated values for the DNA 
content per nucleus are reasonable or not. Thoms o n et al. (1953), who made a number of accurate measurements on various tissues of rats weighing from 195 to $250 \mathrm{~g}$, claim that the average DNA-P content per nucleus from the tissues, such as spleen, kidney, pancreas, small intestine, leukocytes, bone marrow, thymus, heart, lung and salivary glands, lies between $0.65 \times 10^{-9} \mathrm{mg}$ and $0.70 \times 10^{-9} \mathrm{mg}$. As regards the DNA-P content per nucleus in the rat liver, however, divergent values are reported in the literature as follows: $0.60 \times 10^{-9} \mathrm{mg}$

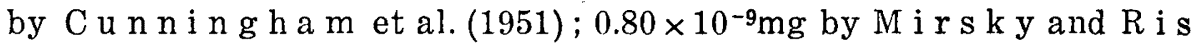
(1952); $0.86 \times 10^{-9} \mathrm{mg}$ by Vendrely, R. and C. Vendrely (1949, $1952) ; 0.90 \times 10^{-9} \mathrm{mg}$ by Thom son et al. (1953); and $1.01 \times 10^{-9} \mathrm{mg}$ by $\mathrm{Har}$ ris on (1951). Of particular interest in this connection is the work of $\mathrm{Fuk} \mathrm{uda}$ and $\mathrm{Si}$ bat a $\mathrm{n} \mathrm{i} \mathrm{(1953b),} \mathrm{who} \mathrm{have} \mathrm{demonstrated}$ that during the earlier course of the postnatal growth of the rat, the average DNA content of liver nuclei shows a certain age variation, and that this value is determined by the maximun body weight which the animals have attained irrespective of growth rate or nutritional conditions. This is one of the main reasons why the animals of constant weight must be used in the present type of measurements.

From the above considerations, it is expected that the values determined for average DNA-P content per nucleus in the different lymphoid tissue of rats of approximately constant weight would agree fairly well with each other. As a matter of fact, no significant differences are to be seen among the following figures obtained: $(0.71 \pm 0.04) \times 10^{-9} \mathrm{mg}$ in the whole lymph nodes; $(0.74 \pm 0.04) \times 10^{-9} \mathrm{mg}$ in the thymus ; $(0.77 \pm 0.04) \times 10^{-9}$ in the spleen; and $(0.68 \pm 0.03) \times 10^{-9}$ $\mathrm{mg}$ in the $\mathrm{P}$ e y e r's patches (Tables 1-5). Furthermore, these values are in good agreement with the figures of $\mathrm{Th}$ o m s o n et al. (1953), who claim that the DNA-P content per nucleus lies between $0.65 \times 10^{-9}$ $\mathrm{mg}$ and $0.70 \times 10^{-9} \mathrm{mg}$ in the rat tissues as already cited. Therefore, the values obtained in the present study for the DNA-P content per nucleus in the lymphoid organs may all be considered to be quite reasonable.

In the present study, the calculated figures for total lymphocytes in the individual as well as in the whole lymphoid organs are slightly greater than the corresponding figures reported in the preliminary communications (M o n d e n, 1955; O s o g o e et al., 1957; O s o goe ; 1958), owing to increase in the number of observations and to more accurate calculations. Hence, it seems desirable to make renewed calculations on the daily production of lymphocytes by mitosis in the 
thymolymphatic organs based on the present data. For the daily mitotic rates in the individual lymphoid organs the figures of $I$ to reported in the preliminary papers (O so go e et al., 1957; O s o goe, 1958 ; and $\mathrm{O}$ s o g o e and $\mathrm{A}$ w a y a, 1958) were used, and the computations were made on a similar assumption as in the earlier studies that the mitotic rate is the same for both the lymphocytic and the non-lymphocytic elements (Table 9). The calculations showed that

Table 9. Average number of lymphocyte mitoses per day in lymphoid organs of normal male rats weighing around $200 \mathrm{~g}$. Mean \pm S. E.

\begin{tabular}{l|c|c|c}
\hline \multicolumn{1}{c|}{ Organ } & $\begin{array}{c}\text { Total Number } \\
\text { of Lymphocytes } \\
\left(\times 10^{3}\right)\end{array}$ & $\begin{array}{c}\text { Total Percentage } \\
\text { of Mitoses } \\
\text { per Day* }\end{array}$ & $\begin{array}{c}\text { Mumber of } \\
\text { Mitos per Day } \\
\left(\times 10^{i}\right)\end{array}$ \\
\cline { 2 - 4 } Thymus & $1,071 \pm 145$ & $22.23 \pm 1.47$ & $238 \pm 47.6$ \\
Mesenteric Lymph Nodes & $684 \pm 123$ & $7.85 \pm 0.70$ & $54 \pm 14.5$ \\
Other Lymph Nodes & $1,031 \pm 106$ & $6.65 \pm 0.51$ & $69 \pm 12.4$ \\
Spleen & $1,100 \pm 169$ & $6.65 \pm 0.51^{* *}$ & $73 \pm 11.8$ \\
Peye r's patches & $382 \pm 34$ & $6.65 \pm 0.51^{* *}$ & $26 \pm 2.5$ \\
\hline Total Lymphoid Organs & $4,268 \pm 577$ & & $460 \pm 88.8$ \\
& & & $\left(361 \pm 74.5^{* * *}\right)$ \\
\hline
\end{tabular}

* The data from the observations of I to reported in the preliminary communications (O s o goe et al., 1957; Osogoe, 1958; and Osogoe and A w a y a, 1958).

** The daily mitotic rate in the spleen as well as in the Peyer's patches is assumed to be equal to that observed in the lymph nodes other than the mesenteric nodes.

*** The figures when the spleen and Peyer's patches are excluded.

the number of mitoses per day amounted to $(238 \pm 47.6) \times 10^{6}$ in the thymus, $(54 \pm 14.5) \times 10^{6}$ in the mesenteric lymph nodes, $(69 \pm 12.4) \times 10^{6}$ in the other lymph nodes, $(73 \pm 11.8) \times 10^{6}$ in the spleen and $(26 \pm 2.5)$ $\times 10^{6}$ in the $\mathrm{P}$ e y e r's patches, totaling $(460 \pm 88.8) \times 10^{6}$ in the whole lymphoid organs. Here, the daily mitotic rate of lymphocytes in the spleen and $\mathrm{Pey}$ e r's patches, in which no mitotic counts had been made, was assumed to be equal to that observed in the lymph nodes other than the mesenteric nodes.

The number of lymphocytes needed for daily growth of the lymphoid tissue was roughly estimated to total $26.6 \times 10^{6}$ in the whole - lymphoid organs, assuming the rate of growth of the tissue to be $0.624 \%$ according to $\mathrm{K} \mathrm{in} \mathrm{dred} \mathrm{(1942).} \mathrm{Subtracting} \mathrm{this} \mathrm{figure} \mathrm{from}$ the number of total lymphocyte mitoses per day in the whole lymphoid organs, the average number of excess mitoses per day in the 
whole thymolymphatic organs was found to be $433 \times 10^{6}$. This is 3.3 times as great as the number of lymphocytes present in the circulating blood ${ }^{4}$.

If we assume that all excess lymphocytes newly produced by mitosss in the lymphoid organs enter into the general circulation, the turnover or renewal time of the lymphocytes in the circulating blood may be estimated to be 0.30 day or 7.2 hours and the "Daily Replacement Factor" (D.R.F.) of Y of $\mathrm{f}$ e $\mathrm{y}$ (1954) for the blood lymphocytes to be 3.3. In the earlier studies (O s o g o e et al., 1957 and O s o g o e, 1958), in which the spleen and Pe yer's patches were not included, the D.R.F. was estimated to be 2.87 or 2.6 .

\section{Summary}

1. In a series of 10 male albino rats of the $W$ is t a $r$ strain weighing aproximately $200 \mathrm{~g}$ each, total cellular number and cellular density in the thymolymphatic organs were estimated chemically by determining DNA-P content of the whole tissue and of each nucleus, using the Sch neider method and diphenylamine test.

2. The values obtained for total nucleated cells in the lymphoid organs were as follows: $(763 \pm 121) \times 10^{6}$ in the mesenteric lymph nodes; $(1,165 \pm 79) \times 10^{6}$ in the other lymph nodes; $(1,094 \pm 144) \times 10^{6}$ in the thymus; $(1,375 \pm 189) \times 10^{6}$ in the spleen; $(420 \pm 33) \times 10^{6}$ in the P e y e r's patches ; and $(4,823 \pm 234) \times 10^{6}$ in the whole thymolymphatic organs.

3. The proportion of lymphocytes to total nucleated cells in imprint preparations was found to be : $89.7 \pm 2.0 \%$ in the mesenteric lymph nodes; $88.5 \pm 2.3 \%$ in the other lymph nodes; $97.9 \pm 0.4 \%$ in the thymus ; $80.7 \pm 1.5 \%$ in the spleen; and $91.0 \pm 1.0 \%$ in the P e y e r's patches.

4. The number of total lymphocytes was ealculated to be: $(684 \pm$ $123) \times 10^{5}$ in the mesenteric lymph nodes; $(1,031 \pm 106) \times 10^{6}$ in the other lymph nodes; $(1,071 \pm 145) \times 10^{6}$ in the thymus; $(1,100 \pm 169) \times$ $10^{6}$ in the spleen; $(382 \pm 34) \times 10^{6}$ in the $\mathrm{P}$ e y e r's patches ; and $(4,268 \pm$ $577) \times 10^{6}$ in the whole thymolymphatic organs. It was estimated that the lymphocyte reserve in the whole thymolymphatic organs is 32 times as great as the number of lymphocytes present in the circulating blood.

5. The estimated figures for total nucleated cells per $1 \mathrm{~mm}^{3}$ of

4 For this calculation an estimate of $(132 \pm 12.0) \times 10^{6}$ was used for the total number of lymphocytes present in the circulating blood (cf. Monden, 1958). 
tissue (cellular density) were as follows: $(1.92 \pm 0.15) \times 10^{6}$ in the mesenteric lymph nodes; $(1.15 \pm 0.06) \times 10^{6}$ in the other lymph nodes; $(2.68 \pm 0.27) \times 10^{6}$ in the thymus; $(1.49 \pm 0.13) \times 10^{6}$ in the spleen; and $(1.57 \pm 0.15)$ in the $\mathrm{P}$ e y e r's patches. Thus, the cellular density is highest in the thymus and it decreases in the following order: mesenteric nodes, P e y e r's patches, spleen, lymph nodes other than the mesenteric nodes.

6. On the basis of the figures obtained, a renewed calculation was made of the daily rate of production of lymphocytes by mitosis in the whole thymolymphatic organs.

\section{References}

Andreasen, E. 1943 Studies on the Thymolymphatic System. Acta path. et microbiol. Scandinav., Suppl. XLIX. Ejar Munksgaard, Copenhagen.

$\mathrm{Cunn}$ in $\mathrm{gh} \mathrm{a} \mathrm{m,} \mathrm{L.,} \mathrm{A.} \mathrm{C.} \mathrm{Grif} \mathrm{in}$ and J. M. L u c k 1950 The desoxypentosenucleic acid content of nuclei of normal, precancerous and neoplastic rat tissues. J. Gen. Physiol., $34: 59-63$.

$\mathrm{Fukuda}, \mathrm{M}$. and A. S i b a tan i 1953a Biochemical studies on the number and composition of liver cells in postnatal growth of the rat. J.Biochem., 40 : $95-110$.

Fukuda, M. and A. Sibat a n i 1953b Relation between the body weight and the average"DNA content of liver nuclei in postnatal growth of the rat. Exp. Cell Res., $4: 236-238$.

$\mathrm{H}$ a r r is o n, M. F. 1951 . Relation between polyploidy and amounts of desoxyribonucleic acid per nucleus in the liver and kidney of adult rat. Nature, 168 : 248-250.

K indred, J. E. 1938 A quantitative study of the lymphoid organs of the albino rat. Am. J. Anat., 62:453-473.

K in d re d, J.E. 1940 A quantitative study of the hematopoietic organs of young albino rats. Am. J. Anat., 67:99-149.

K indred, J.E. 1942 A quantitative study of the hematopoietic organs of young adult albino rats. Am. J. Anat., $71: 207-243$.

K indred, J.E. 1955 Quantitative studies on lymphoid tissues. Ann. New York Acad. Sci., 59 (Art 5) : 746-756.

Mirsky, A.E. and H. R is 1952 The desoxyribonucleic acid content of animal cells and its evolutionary significance. J. Gen. Physiol., 34:451-462.

Monde n, Y. 1955 Total number of lymphocytes contained in the thymo-lymphatic system of rats as estimated by means DNA determination. Acta haemat. Jap., 18:617-624. (In Japanese with English summary.)

Monden, Y. 1958 A quantitative study of cell populations in the circulating blood of young adult albino rats. (To be published.)

O sogoe, B. 1958 A quantitative study of lymphocyte production, with special reference to its relation to myelopoiesis. Saishin-Igaku, 13:1028-1041. (In Japanese.)

Osogoe, B. and K. A wa y 1958 Turnover of cell populations in blood and blood-forming tissue. Acta haemat. Jap., 21 (Suppl.):408-418. 
Osogoe, B., Y. Monden et H. It o 1957 Étude quantitative de la production cellulaire par le système thymo lymphatique du rat. Sang, 28:792-737.

Sanders, A. G. and H.W. F l ore y 1940 The effects of the removal of lymphoid tissue. Brit. J. Exp. Path., $21: 275-287$.

Sa s a ki, M. 1958 Unpublished observations.

Thomson, P.Y., F. C. Heagy, W. C. Hutchis on and J. N. Davidson 1953 The desoxyribonucleic acid content of the rat cell nucleus and its expressing the results of tissue analysis, with particulare reference to the composition of liver tissue. B:ochem. J., $53: 460-474$.

Vendrely, R. et C. Vendrely 1949 La teneur dun oyau cellulaire en acide désoxyribonucléique à travers les organs, les individus et les espèces animals. Experientia, 5: $327-333$.

Vendrely, R. 1952 L'acide désoxyribouncléious du noyau des cellules animals. Bull. biol. Franc. Belg., $86: 1-87$.

Y off ey, J. M. 1954 Bone marrow. Brit. Med. J., 1954, Vol. 2:193-204. 